\title{
Ultrastructure of immature stages of Cochliomyia macellaria (Diptera: Calliphoridae), a fly of medical and veterinary importance
}

\author{
Paloma Martins Mendonça • Rodrigo Rocha Barbosa • Lucas Barbosa Cortinhas • \\ Jacenir Reis dos Santos-Mallet • Margareth Maria de Carvalho Queiroz
}

Received: 21 March 2014 / Accepted: 4 July 2014 / Published online: 16 July 2014

(C) Springer-Verlag Berlin Heidelberg 2014

\begin{abstract}
Cochliomyia macellaria (Diptera: Calliphoridae) is known as the secondary screwworm because it causes secondary or facultative myiasis when the larvae feed on necrotic tissues. This fly has a significant medical and veterinary importance since it has been reported to transport eggs of Dermatobia hominis (human botfly), which can cause significant economic losses to livestock. Since this screwworm has been collected colonizing both pig carcasses and human cadavers, it is considered one of the most important species for forensic entomology studies. Scanning electron microscopy (SEM) gives detailed information on the morphological characteristics which can help identify the immature forms of the flies. The aim of this study was to describe and analyze the morphological characteristics of the eggs, all the larval instars, and the puparia of Cochliomyia macellaria using SEM. The egg is ellipsoid and the dorsal surface is concave. The islands inside the median area had no anastomosis, but some
\end{abstract}

P. M. Mendonça $(\bowtie) \cdot$ R. R. Barbosa $・$ L. B. Cortinhas •

J. R. dos Santos-Mallet • M. M. de Carvalho Queiroz

Laboratório de Transmissores de Leishmanioses, Setor de

Entomologia Médica e Forense, Instituto Oswaldo Cruz, Fundação

Oswaldo Cruz, Av. Brasil 4365, Manguinhos, Rio de Janeiro, RJ,

Brazil

e-mail: palomamm@ioc.fiocruz.br

P. M. Mendonça

Doutoranda do Programa de Pós-Graduação em Ciências

Veterinárias - Universidade Federal Rural do Rio de Janeiro,

Seropedica, RJ, Brazil

R. R. Barbosa

Doutorando do Programa de Pós-Graduação em Biologia Animal -

Universidade Federal Rural do Rio de Janeiro, Seropédica, RJ, Brazil

\section{B. Cortinhas}

Mestrando do Programa de Pós-Graduação em Biodiversidade e Saúde, Instituto Oswaldo Cruz, Fundação Oswaldo Cruz, Rio de Janeiro, RJ, Brazil perforations could be observed. From the second larval instar onwards, besides the intersegmental spines, other bands of spines were observed at the abdominal segments. Two spiracular openings were visible on the first and second larval instars, which were not expected. These characteristics are specific to Cochliomyia genus. The number and the general aspect of the spine tips in the cephalic region, the intersegmental bands on the abdomen, and the number of the spiracular openings could together help identify C. macellaria.

Keywords Fly $\cdot$ Eggs $\cdot$ Larvae $\cdot$ Puparia $\cdot$ Veterinary entomology $\cdot$ SEM

\section{Introduction}

The Calliphoridae family is composed of species with a great variety of feeding and development habits. Immature stages can develop in human and animal feces, putrefied meat, garbage, and other substrates (Queiroz et al. 1999).

The genus Cochliomyia Townsend (Diptera: Calliphoridae) is endemic in the New World, and it is represented by four species, Cochliomyia hominivorax Coquerel, 1858; Cochliomyia aldrichi Del Ponte, 1938; Cochliomyia minima Shannon, 1962; and Cochliomyia macellaria Fabricius, 1775 (Guimarães and Papavero 1999).

Cochliomyia macellaria is known as the secondary screwworm because it causes secondary or facultative myiasis when the larvae feed on necrotic tissues (Guimarães and Papavero 1999). This fly has a significant medical and veterinary importance since it has been reported to transport eggs of Dermatobia hominis (human botfly) (L. Jr, 1781) (Diptera: Oestridae), which can cause significant economic losses to livestock (Grisi et al. 2002). 
In Brazil, besides C. macellaria, only $C$. hominivorax of the genus Cochliomyia Townsend is found (Guimarães and Papavero 1999). The general aspect of the immature forms of these flies and the lesions caused by them are very similar, so it is essential to be able to identify them correctly. $C$. hominivorax is one of the most important parasitic diseases of domestic animals in South America, especially in Brazil (Anziani et al. 2000).

According to Erzinclioglu (1989), some species of flies are found on dead bodies and their larvae can help to determine the postmortem interval (PMI). This screwworm C. macellaria, as some others, could be useful to determine the PMI in forensic cases. However, Owings et al. (2014) described the increase in pupae size of $C$. macellaria collected at three different ecoregions in Texas. These authors proposed that environmental conditions could influence puparia and adult size. The influence of abiotic factors at immature development should also be carefully considered to determine PMI.

The immature forms of the family Calliphoridae are very similar, and this screwworm fly has been collected rearing on both animal and human corpses, together with other Calliphoridae maggots (Barreto et al. 2002; Gruner et al. 2007; Velásquez 2008). The insects collected rearing on carcasses are the immature forms, so the correct identification of these insects is very important to help entomologists estimate the postmortem interval. However, since these insects are usually preserved in ethanol, when collected, they cannot be reared to adults.

The screwworm C. macellaria and the blowfly Lucilia cuprina were the major species collected from a pig carcass in Temuco, Chile (Ortloff et al. 2012). Other authors have also related this fly colonizing animal carcasses (Biavati et al. 2010; Catts and Goff 1992; Oliva 2001) and also human cadavers (Oliveira and Vasconcelos 2010).

Skoda et al. (2013) used random amplified polymorphic DNA-polymerase chain reaction (RAPD-PCR) for interspecific and intraspecific identification of $C$. hominivorax. Besides RAPD-PCR, some other molecular approaches have been used to identify diptera and other insects, such as barcode (Hebert et al. 2003; Nelson et al. 2007, 2012). Molecular biology techniques do not require the whole insect to be done; this approach is relatively cheap and fast. At the same time, there are few sequences available at data sets, mainly at Brazilian forensic species. Besides that, molecular biology results are not related with the developmental stage. Light and scanning electron microscopy, at this case, could provide better results.

Florez and Wolff (2009) described the immature stages of C. macellaria using light microscopy but only provided drawings of the general aspects and the cephalopharyngeal skeleton due to the visible limitations of this technique. Liu and Greenberg (1989) pointed out some characteristics of the immature forms of this New World screwworm. However, scanning electron microscopy (SEM) could provide a more detailed characterization of these maggots (Mendonça et al. 2010, 2012a, b, 2013; Liu and Greenberg 1989).
The aim of this study was to describe and analyze the morphological characteristics of the eggs, all the larval instars, and the puparia of $C$. macellaria using SEM.

\section{Material and methods}

All the immature forms examined in this study were obtained from a culture derived from wild $C$. macellaria collected using liver bovine and putrefied meat as bait in the city of Macapá, Amapá State, Brazil, according to Barbosa et al. (2009). The colonies were reared and maintained at the Setor de Entomologia Médica e Forense that is part of the Laboratório de Transmissores de Leishmanioses, in the state of Rio de Janeiro, as previously described (Queiroz and Milward-de-Azevedo 1991). The insects were kept in cages at room temperature and supplied with water and sugar ad libitum. Protein in the form of bovine meat was given to stimulate oviposition, and the females readily oviposited on this medium. The new generation was reared as described earlier, and immature stages from the third laboratoryhatched generation were used for this study. Eggs were washed in $2 \%$ sodium hydroxide, and later, eggs, larvae, and puparia were washed several times in distilled water. Larvae were killed by placing them in hot water for $5 \mathrm{~min}$. Eggs and larvae were fixed in $2.5 \%$ glutaraldehyde in a $0.1-\mathrm{M}$ sodium cacodylate buffer, $\mathrm{pH}$ 7.2 , for $1 \mathrm{~h}$ and postfixed in $1 \%$ osmium tetroxide in the same buffer for $1 \mathrm{~h}$ at room temperature in the dark. These immature forms were washed with sodium cacodylate buffer three times for $10 \mathrm{~min}$ each. Afterward, they were dehydrated in an ascending series of acetone up to $100 \%$ and submitted to the critical point drying method, using superdry $\mathrm{CO}_{2}$ in a Balzers apparatus (Hayat 1970). Specimens were placed on metallic supports, coated with a thin layer of gold (20-30 nm), and examined under a Jeol JSM 6390LV scanning electron microscope (Akishima, Tokyo, Japan). The SEM images were transferred directly to a computer.

Puparia were not submitted to any kind of chemical fixation. Puparia were put under refrigeration for $5 \mathrm{~min}$, and then they were placed onto double-stick tape on metallic supports, coated with gold, and examined under the same SEM. Ten specimens of each immature stage were analyzed. The terminology used in describing the morphology in this work followed Margaritis (1985) and Mc Alpine et al. (1981).

\section{Results}

\section{Eggs}

The egg is ellipsoid and the dorsal surface is concave (Fig. 1a). The eggshell is smooth and the average size is $1.31 \pm 0.06 \mathrm{~mm}$ long and $324.33 \pm 51.5 \mu \mathrm{m}$ wide. The anterior region is slightly tapered compared with the posterior end, and the median area is continuous along the egg (Fig. 1a). At the anterior region, the 


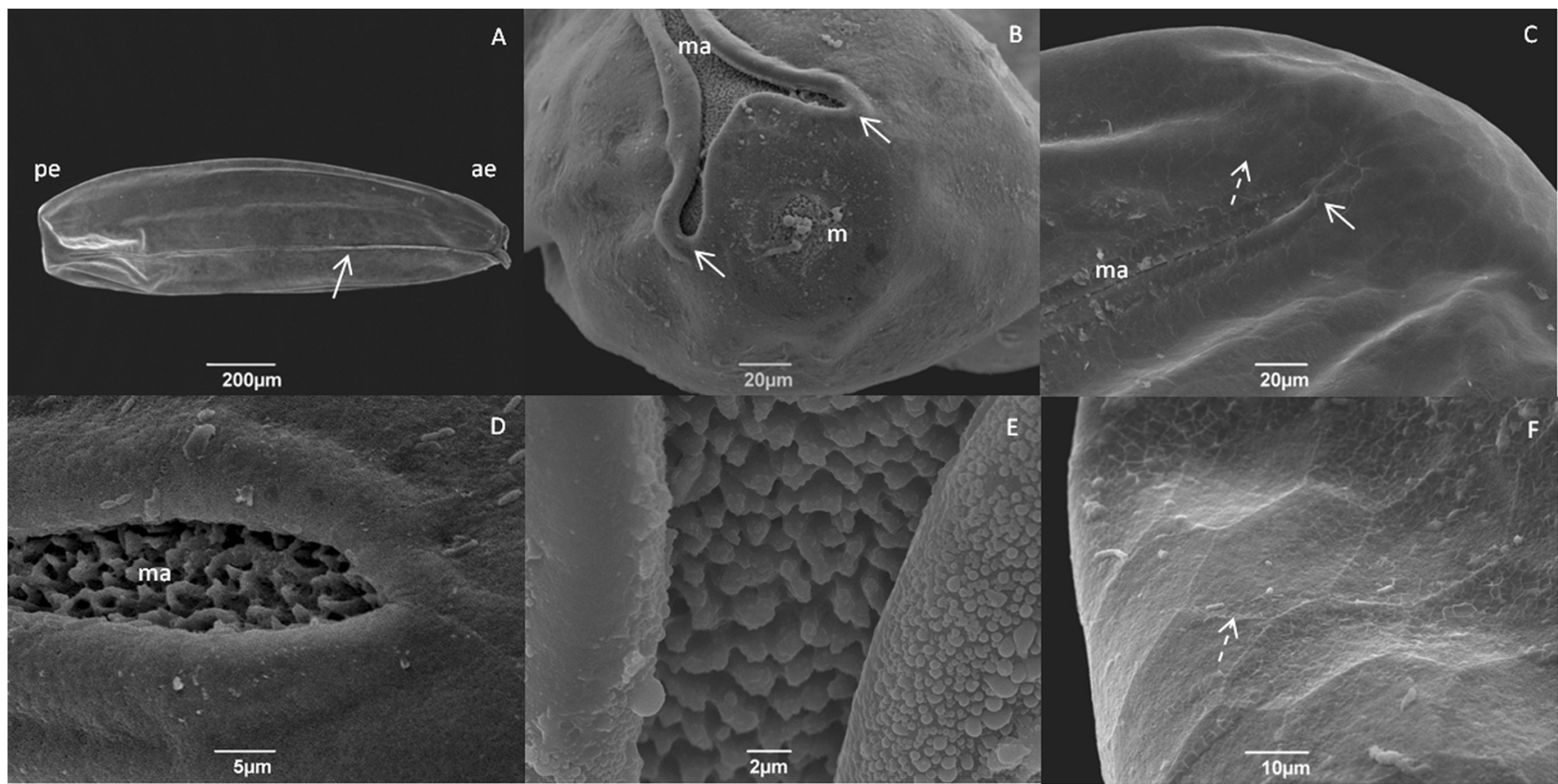

Fig. 1 Scanning electron micrographs of an eggshell of Cochliomyia macellaria (Diptera: Calliphoridae). a Dorsal view, anterior end at right $(a)$, posterior end on the left ( $p e)$; median area $(m a)$ extending the entire length of the egg (arrow) $(\times 650)$. b Median area $(m a)$ ending in a "Y" anteriorly (arrows), next to the micropyle $(m)(\times 650)$. c Dorsal view,

median area reaches the micropyle in a "Y" shape (Fig. 1b). The micropyle is an orifice with some projections around it (Fig. 1b). At the posterior region, the median area ends tapered (Fig. 1c, d). The islands inside the median area had no anastomosis, but some perforations could be observed (Fig. 1d, e). The chorionic cells exhibited a hexagonal pattern with thin edges (Fig. 1f).

\section{First instar larvae}

The average size of the larval body was $1.79 \pm 0.23 \mathrm{~mm}$ long and $230.19 \pm 98.01 \mu \mathrm{m}$ wide and is composed of 12 segments (one cephalic, three thoracic, and eight abdominal) separated by groups of spines with different shapes and sizes (Fig. 2a). The cephalic region has a longitudinal line that divides the first segment into two lobes (Fig. 2b). On each side, the domed-shaped antennae and the maxillary palp complex can be seen; the oral cristae are two elongated lines situated transversally to the cephalic region (Fig. 2b, c). The dental sclerites have a fringe-like appearance, and the spines near the cephalic region are flattened, but near the thoracic segment are slender (Fig. 2c, d). However, the spines between the other segments are all flattened (Fig. 2e). An anterior spiracle is not visible in this larval instar. The posterior end of the first larval instar is blunt, but only anal tubercles are clearly visible, all the others are too small. A pair of posterior spiracles is located on this segment with two spiracular openings and strong muscles are visible (Fig. 2f). median area ( $m a$ ) ending tapered (arrow); chorionic cells (dashed arrow) $(\times 650)$. d Dorsal view, details of the median area $(m a)$ ending tapered $(\times 3,000)$. e Islands in the median area without anastomosis $(\times 5,500)$. $\mathbf{f}$ Detail of the chorionic cells (dashed arrow) $(\times 1,600)$

\section{Second instar larvae}

The body of the second instar larvae is similar in shape to the first instar (Fig. 3a). The average size is $2.08 \pm 0.22 \mathrm{~mm}$ long and $368.62 \pm 65.11 \mu \mathrm{m}$ wide. The cephalic region is more developed, and the antennae and maxillary palp complex are more visible (Fig. 3b, c). The antennae are composed of three segments, and the five sensorial papillae form the maxillary palp complex (Fig. 3b, c). The oral cristae are formed by a group of parallel laminar structures that are much more developed than those observed in the first instar larvae (Fig. 3b). Dental sclerites still with a fringe-like appearance and the spines of the cephalic region are flattened but more robust (Fig. 3b, e). The ventral organ is located at the oral cristae, below the maxillary palp complex (Fig. 3d).

The anterior spiracle is composed of a row of 11-12 spiracular ramifications (Fig. 3f). A pair of Keilin's organs is present, ventrally, at each thoracic segment (Fig. 3g). The intersegmental spines are all flattened, as those observed on the first instar larvae. However, with this instar, besides the intersegmental spines, other bands of spines were observed at the abdominal segments (Fig. 3h). These spines are smaller than those of the intersegmental band.

An opened peritreme is located on the top of a slight elevation. Two spiracular openings are sustained by strong spiracular muscles at the posterior spiracle (Fig. 3i). 


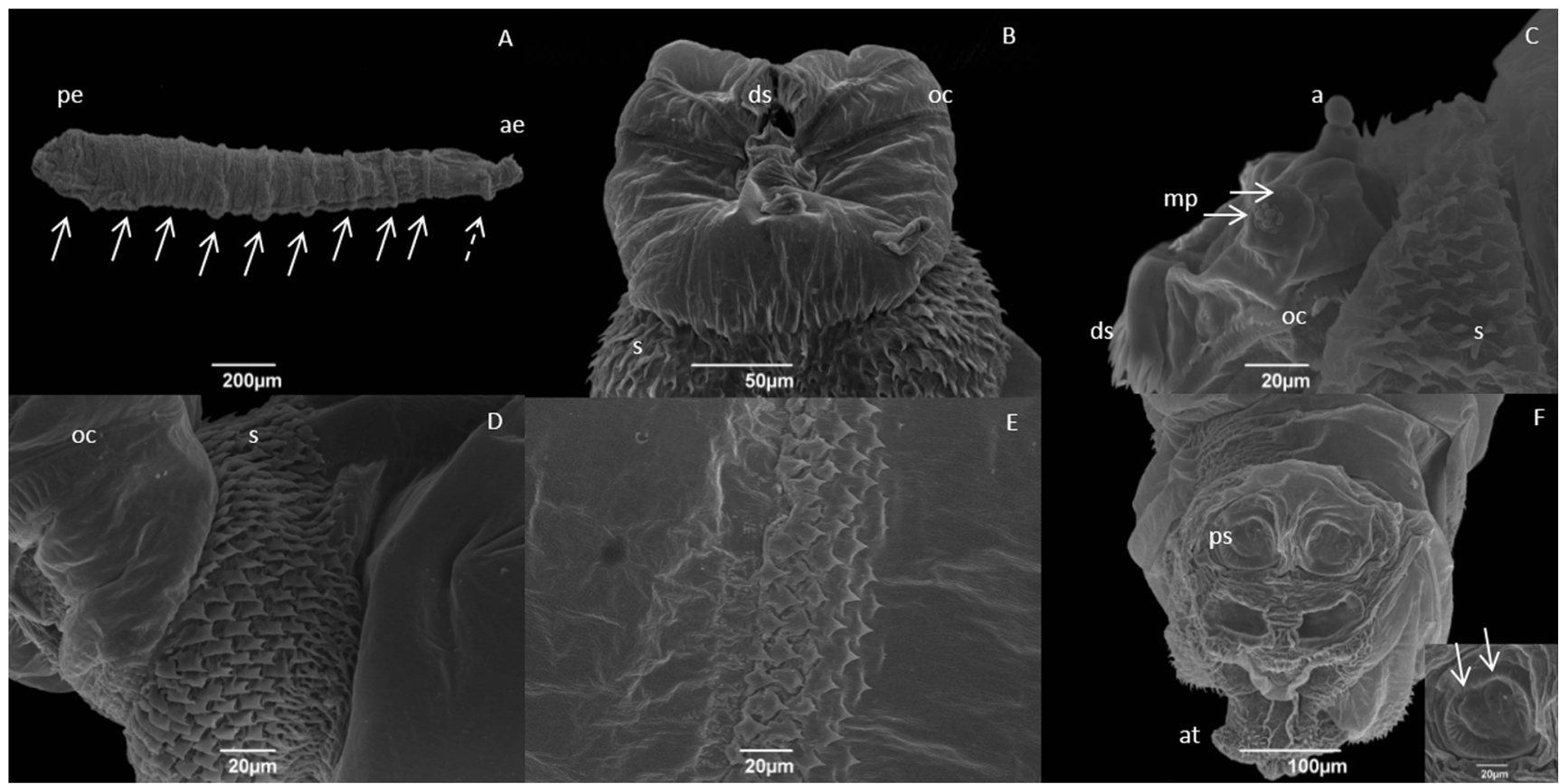

Fig. 2 Scanning electron micrographs of a first instar larvae of Cochliomyia macellaria (Diptera: Calliphoridae). a Larval body composed of groups of spines located between the segments (arrows) and the anterior (ae) and posterior ends (pe) of larval body; cephalic spines (dashed arrow) $(\times 80)$. b Cephalic region with dental sclerites $(d s)$, oral cristae $(o c)$, and cephalic spines $(\mathrm{s})(\times 500)$. c Detail of cephalic region

\section{Third instar larvae}

The general aspect of the third larval instar is similar to the first and second instars, except for the size (average size is 10.86 \pm $1.25 \mathrm{~mm}$ long and $1.62 \pm 0.49 \mathrm{~mm}$ wide) (Fig. 4a). However, both the intersegmental spines and the other bands of spines of this instar were more developed (Fig. 4a, e). The cephalic region is fully developed, and all the structures showed the same aspect as observed in the previous instar (Fig. 4b). The papillae of the maxillary palp complex are more visible (Fig. 4c). The spines at the cephalic region are varied, some are flattened with two or more tips and some are slender (Fig. 4d). The intersegmental spines are flattened with two tips directed backwards, and the other bands of spines have a similar aspect, but are smaller and robust (Fig. 4e). The intersegmental line is not complete at the abdominal segments six and seven.

The anterior spiracle is composed of a single row of 12 spiracular ramifications (Fig. 4f). An opened peritreme is also located on the top of an elevation, but in a slight cavity surrounded by tubercles (Fig. 4g, h). The ecdysial scar is absent, and the three spiracular openings have a radial orientation (Fig. 4h)

\section{Puparia}

The puparia is blunt at the posterior end and pointed at the other end. The average size of the puparia is $4.92 \pm 0.62 \mathrm{~mm}$ with antennae ( $a$ ), maxillary palp ( $m p$, arrows), dental sclerites $(d s)$, oral cristae $(o c)$, and cephalic spines $(s)(\times 800)$. d Cephalic spines $(s)$ between the first segment, the oral cristae $(o c)$, and thoracic region $(\times 700)$. e Spines between the thoracic and abdominal segments $(\times 650)$. f Anal segment with anal tubercles and posterior spiracles $(p s)(\times 250)$; detached: posterior spiracle with two spiracular openings $($ arrows $)(\times 700)$

long and $2.78 \pm 0.38 \mathrm{~mm}$ wide (Fig. 5a). The cephalic region is retracted, and the anterior spiracle is at the most anterior point of the puparia (Fig. 5a-c). No cephalic structures are visible in the puparia (Fig. 5b, c). The anterior spiracle is composed of a row of 12 spiracular ramifications (Fig. 5d). The integument is composed of rows of intersegmental spines with two tips, but these segments showed wrinkles different from the third instar larvae integument (Fig. 5e, f).

An opened peritreme without a ecdysial scar was visible. The three spiracular openings had a radial orientation. Due to the cuticular sclerotization of the third instar larvae to give origin to the puparia, the peritreme is not located in a cavity (Fig. 5g).

\section{Discussion}

Calliphoridae species are very similar, both adults and the immature forms. C.macellaria was described by Florez and Wolff (2009) using light microscopy and by Liu and Greenberg (1989) who used scanning electron microscopy. However, all these authors only focused on the general aspects of some features. Cochliomyia hominivorax is the only cogenera species described since this fly is important as a myiasis agent (d'Almeida and Lopes 1983; Erzinclioglu 1989; Leite and Guevara 1993; Szpila et al. 2014; Zumpt 1965). 


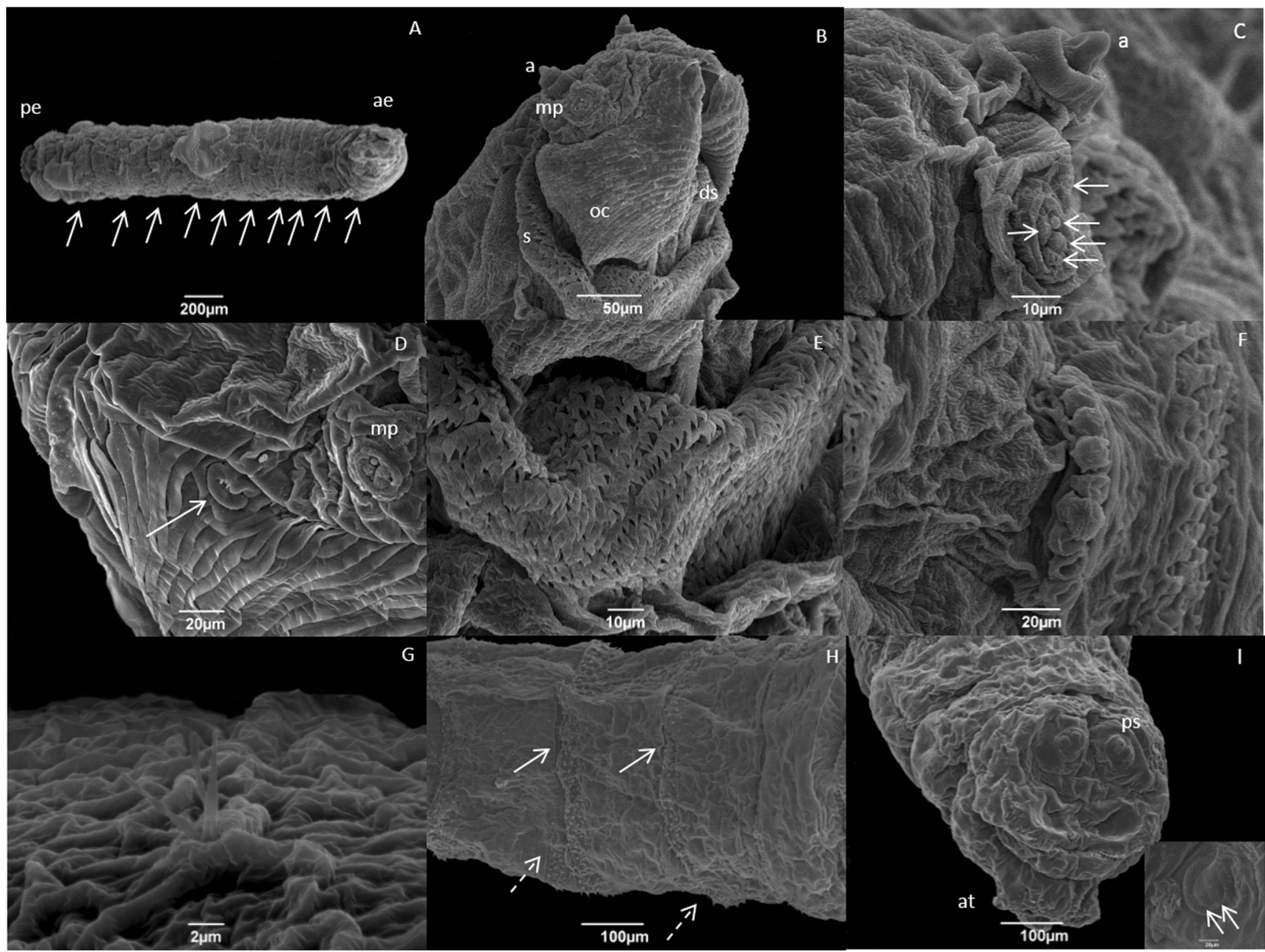

Fig. 3 Scanning electron micrographs of a second instar larvae of Cochliomyia macellaria (Diptera: Calliphoridae). a Larval body composed of groups of spines located between the segments (arrows) and the anterior $(a e)$ and posterior ends $(p e)$ of larval body $(\times 60)$. b Cephalic region with antennae $(a)$, maxillary palp $(m p)$, dental sclerites $(d s)$, oral cristae $(o c)$, and cephalic spines $(s)(\times 400)$. c Detail of cephalic region with antennae $(a)$ and maxillary palp (arrows) $(\times 1,500)$. d Ventral organ (arrow) next to maxillary palp complex $(m p)(\times 700)$. e Cephalic spines $(s)$ between the cephalic region and the first thoracic segment $(\times 1,200)$. $\mathbf{f}$ Anterior spiracle $(\times 900)$. g Keilin's organ $(\times 5,500)$. h Intersegmental spines (arrows) and band of spines (dashed arrows) $(\times 190)$. i Anal segment with anal tubercles and posterior spiracles $(p s)(\times 190)$; detached: posterior spiracle with two spiracular openings $($ arrows $)(\times 500)$

However, according to Guimarães and Papavero (1999), there have been some misidentifications in myiasis caused by C. hominivorax and C. macellaria.

Eggs of C. macellaria are ellipsoids and the dorsal surface is concave, like other fly eggs (Hinton 1981). Liu and Greenberg (1989) reported that the median area of C. macellaria extended to less than half of the micropyle. This arrangement was also observed for C. macellaria eggs collected in Brazil. However, this characteristic is not enough to distinguish this specie since this feature is common to other fly species (Erzinclioglu 1989; Peterson and Newman Junior 1991; Mendonça et al. 2008; Sukontason et al. 2004a, b).

The chorionic structure of C. macellaria eggs is very similar to C. hominivorax and Chrysomya megacephala. Peterson and Newman Junior (1991) reported the decreased size of the polygonal imprints of the chorionic cells observed in $C$. hominivorax. Comparing the screwworm fly eggs, of C. macellaria, all chorionic cells have the same size. Mendonça et al. (2008) described the islands inside the median area without anastomosis only for $C$. megacephala, as observed by us in C. macellaria. However, those authors did not report any perforations in the blowfly eggs, but holes were clearly visible in the screwworm eggs. The combination of these characteristics could be used to distinguish between the eggs of the different Calliphoridae species.

Eggs are very similar and sometimes there is not any diagnostic feature to identify them (Erzinclioglu 1989). Meanwhile, larvae can offer more diagnostic characteristics than eggs.

Calliphorids are similar, both adults and immature, comparing Neotropical and Neartic species (Queiroz et al. 1997; Mendonça et al. 2012a, b, 2010; Sukontason et al. 2004a, b). 


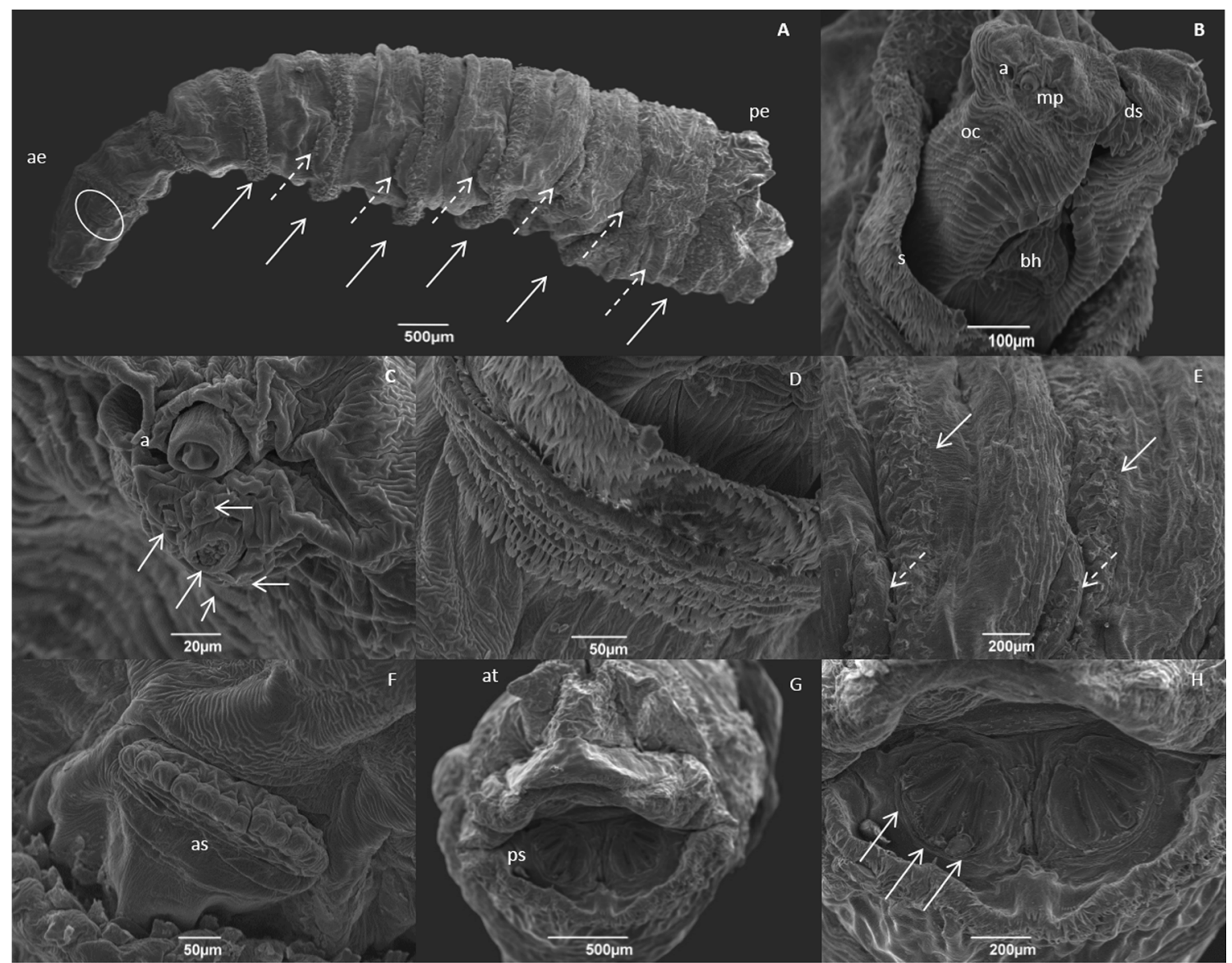

Fig. 4 Scanning electron micrographs of a third instar larvae of Cochliomyia macellaria (Diptera: Calliphoridae). a Larval body composed of groups of spines located between the segments (arrows), band of spines (dashed arrows), anterior (ae) and posterior ends ( $p e$ ) of larval body, anterior spiracle in an ellipse $(\times 30)$. b Cephalic region with antennae (a), maxillary palp ( $\mathrm{mp}$ ), buccal hook (bh), oral cristae (oc), dental sclerites $(d s)$, and cephalic spines $(s)(\times 200)$. c Detail of cephalic region

The antennae or the dorsal organ presented a domed shape; the terminal organ or maxillary palp complex formed by five papillae and ventral organ are typically observed for the Chrysomya species, Musca domestica, and C. hominivorax (Leite and Guevara 1993; Mendonça et al. 2008; Szpila et al. 2014; Szpila and Pape 2008).

In the screwworm $C$. macellaria, the anterior spiracle is composed of a row of 11-12 spiracular ramifications. Liu and Greenberg (1989) did not describe this structure for C. macellaria; Leite and Guevara (1993) stated nine openings in $C$. hominivorax. Therefore, the number of spiracular openings could be used to distinguish among these Cochliomyia species.

Florez and Wolff (2009) described the spines of the cephalic region as strongly pigmented, and they presented one or two tips. The spines of the cephalic region are pointed backwards, flattened, and robust, but some spines showed three or more tips and some were slender. Szpila et al. (2014) and Leite and with antennae $(a)$ and maxillary palp (arrows) $(\times 800)$. d Cephalic spines $(s)$ between the cephalic region and the first thoracic segment $(\times 350)$. e Intersegmental spines (arrows) and band of spines (dashed arrows) $(\times 75)$. f Anterior spiracle $(a s)(\times 270)$. $\mathbf{g}$ Anal segment with anal tubercles and posterior spiracles $(p s)(\times 50)$. $\mathbf{h}$ Posterior spiracle with three spiracular openings (arrows) $(\times 95)$

Guevara (1993) related very robust spines with single or double tips for $C$. hominivorax.

Florez and Wolff (2009) also observed an extra band of spines at abdominal segments of $C$. macellaria, but these authors did not make any distinction among the spines. The spines of the extra band are smaller and more robust than those of the intersegmental band. This structure is also visible in C. hominivorax (Szpila et al. 2014).

According to Guimarães and Amorim (2006), the number of spiracular openings at the posterior spiracle helps to identify the larval instar. However, for the genus Cochliomyia, this statement is only partially true. For the first and second larval instars of $C$. macellaria, two spiracular openings were observed. For the third instar and puparia, three spiracular openings were observed, as expected. The same was observed by Leite and Guevara (1993) for C. hominivorax. The other authors who have studied both species did not mention this feature. 
Fig. 5 Scanning electron micrographs of a puparia of Cochliomyia macellaria (Diptera: Calliphoridae). a Ventral view of puparia, blunt posteriorly (right), and pointed anteriorly (left); anterior spiracle (arrow) and spines between the segments $(s)$ $(\times 23)$. b Cephalic region with anterior spiracle (arrow), dental sclerites (ellipse), and spines $(s)$ $(\times 70)$. c Frontal view of cephalic region with anterior spiracle (arrow), dental sclerites (ellipse), and spines $(s)(\times 60)$. d Frontal view of anterior spiracle (arrow) $(\times 170)$. e Spines between the segments $(s)(\times 37)$, $\mathbf{f}$ Details of spines between the segments $(s)$ $(\times 150)$. g Posterior spiracle with three spiracular openings (arrows) $(\times 60)$

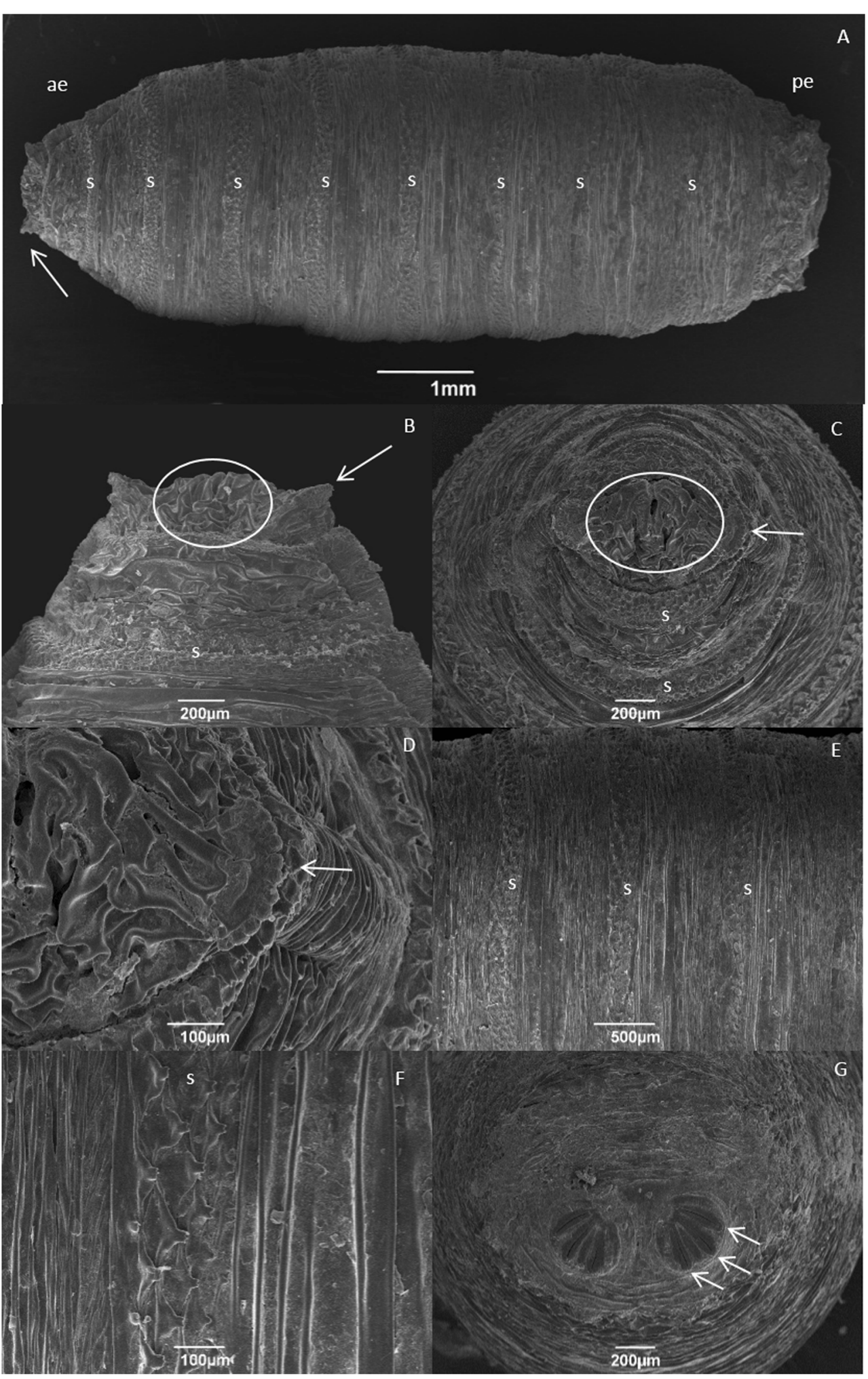

So, as said before, for the immature forms of C. macellaria, there is no single characteristic that can distinguish them neither from among the genus Cochliomyia nor from the other Calliphoridae. The general aspect and number of tips on the spines of the cephalic region, the bands of intersegmental spines, and the number of spiracular openings combined are the main characteristics to identify $C$. macellaria.

Acknowledgments We would like to thank the Platform Electron Microscopy Rudolf Barth of Instituto Oswaldo Cruz (FIOCRUZ) for 
the use of the scanning electron microscope. This work was supported by grants from Instituto Oswaldo Cruz (IOC/FIOCRUZ), Conselho Nacional de Desenvolvimento Científico e Tecnológico (CNPq), Fundação Carlos Chagas Filho de Amparo à Pesquisa do Estado do Rio de Janeiro (FAPERJ), and Coordenação de Aperfeiçoamento de Pessoal de Nível Superior (CAPES).

\section{References}

Anziani OS, Flores SG, Moltedo H, Derozier C, Guglielmone AA, Zimmermann GA, Wanker O (2000) Persistent activity of doramectin and ivermectin in the prevention of cutaneous myiasis in cattle experimentally infested with Cochliomyia hominivorax. Vet Parasitol 87(2-3):243-247

Barbosa RR, Mello-Patiu CA, Mello RP, Queiroz MMC (2009) New records ofcalyptrate dipterans (Fanniidae, Muscidae and Sarcophagidae) associated withthe decomposition of domestic pigs in Brazil. Mem Inst Oswaldo Cruz 104:923-926.

Barreto M, Burbano ME, Barreto P (2002) Flies (Calliphoridae, Muscidae) and beetles (Silphidae) from human cadavers in Cali, Colombia. Mem Inst Oswaldo Cruz 97(1):137-138

Biavati GM, Santana FHAR, Pujol-Luz JR (2010) A checklist of Calliphoridae blowflies (Insecta, Diptera) associated with a pig carrion in central Brazil. J Forensic Sci 55(6):1603-1606

Catts EP, Goff ML (1992) Forensic entomology in criminal investigations. Annu Rev Entomol 37:253-272

d'Almeida JM, Lopes HS (1983) Sinantropia de dípteros caliptratos (Calliphoridae) no estado do Rio de Janeiro. Arq Univ Fed Rural do Rio de Janeiro 6(1):39-48

Erzinclioglu YZ (1989) The value of chorionic structure and size in the diagnosis of blowfly eggs. Med Vet Entomol 3:281-285

Florez E, Wolff M (2009) Descripción y Clave de los Estadios Inmaduros de las Principales Especies de Calliphoridae (Diptera) de Importancia Forense en Colombia. Neotropical Entomol 38(3):418-429

Grisi L, Massard CL, Moya-Borja GE, Pereira JB (2002) Impacto econômico das principais ectoparasitoses em bovinos no Brasil. A Hora Veterinária 125:8-10

Gruner SV, Slone DH, Capinera JL (2007) Forensically important Calliphoridae (Diptera) associated with pig carrion in rural northcentral Florida. J Med Entomol 44(3):509-515

Guimarães JH, Amorim DS (2006) Diptera. In: Costa C, Ide S, Simonka CE (eds) Insetos imaturos: metamorfose e, identificaçãoth edn. Holos, São Paulo

Guimarães JH, Papavero N (1999) Mí́asis in man and animals in Neotropical region. ed. Pleiade/FAPESP, São Paulo.

Hayat MA (1970) Principles and techniques of electron microscopy. In: Biological applications. Van Nostrand Reinhold Company, New York

Hebert PDN, Ratnasingham S, deWaard JR (2003) Barcoding animal life: cytochrome $\mathrm{c}$ oxidase subunit 1 divergences among closely related species. Proc R Soc Lond B 270:S96-S99

Hinton HE (1981) Biology of insect eggs. ed. Pergamon Press, Oxford.

Leite ACR, Guevara JDE (1993) Scanning electron microscopy of the larval instars of Cochliomyia hominivorax. Med Vet Entomol 7: 263-270

Liu D, Greenberg B (1989) Immature stages of some flies of forensic importance. Ann Entomol Soc Am 82:80-93

Margaritis LH (1985) Structure and physiology of eggshell. In: Kerkut GA, Gilbert LI (eds) Comprehensive insect physiology, biochemistry and pharmacology. v.I. Embryogenesis and reproduction. Pergamon Press, Oxford, pp 151-230

Mc Alpine JF, Peterson BV, Shewell GE, Teskey JH, Vockeroth JR, Wood DN (1981) Manual of Neartic Diptera, Ottawa.
Mendonça PM, Santos-Mallet JR, Mello RP, Gomes L, Queiroz MMC (2008) Identification of fly eggs using scanning electron microscopy for forensic investigations. Micron 39:802-807

Mendonça PM, Santos-Mallet JR, Queiroz MMC (2010) Ultramorphological characteristics of immature stages of Chrysomya albiceps (Wiedemann 1819) (Diptera: Calliphoridae), a fly specie of forensic importance. Micr Res Tech 73:779-784

Mendonça PM, Santos-Mallet JR, Queiroz MMC (2012a) Ultrastructure of larvae and puparia of the blowfly Chrysomya megacephala (Diptera: Calliphoridae). Micr Res Tech 75:935939

Mendonça PM, Santos-Mallet JR, Queiroz MMC (2012b) Ultrastructure of immature stages of the blowfly Chrysomya putoria (Wiedemann, 1818) (Diptera: Calliphoridae). Micr Res Tech 75:206-211

Mendonça PM, Barbosa RR, Cortinhas LB, Santos-Mallet JR, Queiroz MMC (2013) Ultrastructure of immature stages of Peckia (Euboetcheria) collusor (Diptera: Sarcophagidae). Acta Trop 128: 522-527

Nelson LA, Wallman JF, Dowton M (2007) Using COI barcodes to identify forensically and medically important blowflies. Med Vet Entomol 21:44-52

Nelson LA, Lambkin CL, Batterham P, Wallman JF, Dowton M, Whiting MF, Yeates DK, Cameron SL (2012) Beyond barcoding: a mitochondrial genomics approach to molecular phylogenetics and diagnostics of blowflies (Diptera: Calliphoridae). Gene 511:131-142

Oliva A (2001) Insects of forensic significance in Argentina. Forensic Sci Int 120(1-2):145-154

Oliveira TC, Vasconcelos SD (2010) Insects (diptera) associated with cadavers at the institute of legal medicine in Pernambuco, Brazil: implications for forensic entomology. Forensic Sci Int 198(1-3):97102

Ortloff A, Peña P, Riquelme M (2012) Preliminary study of the succession pattern of necrobiont insects, colonising species and larvae on pig carcasses in Temuco (Chile) for forensic applications. Forensic Sci Int 222(1-3):e36-e41

Owings CG, Spiegelman C, Tarone AM, Tomberlin JK (2014) Developmental variation among Cochliomyia macellaria Fabricius (Diptera: Calliphoridae) populations from three ecoregions of Texas, USA. Int J Legal Med. doi:10.1007/s00414-014-1014-0

Peterson RD, Newman Junior SM (1991) Chorionic structure of the egg of the screwworm Cochliomyia hominivorax (Diptera: Calliphoridae). J Med Entomol 28:152-160

Queiroz MMC, Milward-de-Azevedo EMV (1991) Técnicas de criação e alguns aspectos da biologia de Chrysomya albiceps (Wiedemann) (Diptera, Calliphoridae), em condições de laboratório. Rev Bras Zool 8:75-84

Queiroz MMC, Mello RP, Lima MM (1997) Morphological aspects of the larval instars of Chrysomya albiceps (Diptera: Calliphoridae) reared in the laboratory. Mem Inst Oswaldo Cruz 92:187-196

Queiroz MMC, Norberg NA, Maure EAP, Toledo RF, Gazêta GS, Dutra AEA, Rodrigues-Guimarães R (1999) Veiculação de bactérias patogênicas por moscas sinantrópicas coletadas em restaurantes, hospitais e feiras da Baixada Fluminense, Rio de Janeiro, Brasil. [Apresentação no XIV Congresso Latinoamericano de Parasitologia; Acapulco, Guerrero; México].

Skoda SR, Figarola JL, Pornkulwat S, Foster JE (2013) Inter- and intraspecific identification of the screwworm, Cochliomyia hominivorax, using random amplified polymorphic DNApolymerase chain reaction. J Insect Sci 13:76

Sukontason K, Sukontason KL, Ngern-Klun R, Sripakdee D, Piangjai S (2004a) Differentiation of the third instar of forensically important fly species in Thailand. Ann Entomol Soc Am 97(6):1069-1075 
Sukontason K, Sukontason KL, Boonchu N, Chaiwong T, Piangjai S (2004b) Ultrastructure of eggshell of Chrysomya nigripes Aubertin (Diptera: Calliphoridae). Parasitol Res 93:151-154

Szpila K, Pape T (2008) Morphology of the first instar of the house fly Musca domestica (Diptera: Muscidae). J Med Entomol 45(4):594-599

Szpila K, Hall MJR, Wardhana AH, Pape T (2014) Morphology of the first instar larva of obligatory traumatic myiasis agents (Diptera:
Calliphoridae, Sarcophagidae). Parasitol Res. doi:10.1007/s00436$014-3808-\mathrm{x}$

Velásquez Y (2008) A checklist of arthropods associated with rat carrion in a montane locality of northern Venezuela. Forensic Sci Int 174(1): 68-70

Zumpt F (1965) Myiasis in man and animals in the old world. ed. Butterworths. London. 